\title{
Habitat use and home range of a migratory bird, Myiodynastes maculatus solitarius, in an urban park in the Atlantic Forest, Brazil
}

\author{
Juliana Gomes Vitório ${ }^{1,3^{*}}$, Rita de Cássia Frenedozo ${ }^{1} \&$ Karlla Vanessa de Camargo Barbosa $^{2^{*}}$ \\ Universidade Cruzeiro do Sul (UNICSUL), São Paulo, Brazil. \\ Instituto de Biociências, Universidade Estadual Paulista (UNESP), Rio Claro, Brazil. \\ Corresponding author: juliana.vitoriovieira@gmail.com \\ Both authors contributed equally to this work
}

Received on 08 March 2019. Accepted on 03 July 2019.

\begin{abstract}
Detailed studies on the home range size and habitat use of a species are important for the understanding of population dynamics and density. The Southern Streaked Flycatcher (Myiodynastes maculatus solitarius) is a common, widely distributed austral migrant in Brazil that inhabits open areas, forest edges and urban parks. Surprisingly, very little information exists on even basic aspects of its natural history, and details about its habitat use and home range are essentially unknown. We estimated home range size and habitat selection by M. m. solitarius during the 2017-2018 breeding season at Parque Ecológico do Tietê, an urban park in São Paulo, Brazil. We mist-netted and banded three adult individuals, which were followed for a total of $91 \mathrm{~h}$ and 50 min to assess their habitat use and home range. Home range size was $5.40 \pm 2.45$ ha (95\% kernel density) and $2.46 \pm 1.70$ ha (50\% kernel density). We obtained 428 sight records of the three individuals, and the strata most frequently used were the canopy and mid-story, in some places with a relatively high percentage of tree cover. These individuals had a clear preference for forested areas $(n=408)$, as compared to isolated trees in open areas $(n=20)$. This study contributes to enhance our knowledge of the natural history of the species and offers important new data on various aspects related to the use of space. These results also suggest that urban green areas promote the occurrence of this species in cities, using urban parks to breed and as stopover sites during migration.
\end{abstract}

KEY-WORDS: behavior, bem-te-vi-rajado, São Paulo, Streaked Flycatcher, urbanization.

\section{INTRODUCTION}

The urbanization process may affect migratory bird species in many different ways, since they use different sites through the year for wintering, stopover and breeding (Martin \& Finch 1995, Lees \& Martin 2015). Moreover, annual variation in urban food resource availability may favor the permanence of resident species and negatively affect migratory species, due to interspecific competition for food and nesting sites (Leveau 2018). For this reason, the structure of urban green areas and heterogeneity of the urban matrix may influence a variety of natural history traits of these species, such as habitat use and home range size.

Home range is the area used by the individual during its daily activities, including foraging and reproduction (Burt 1943, Brown \& Orians 1970, Powell 2000), and it is expected that a bird species meets its basic needs within its home range (Hutto 1985). The habitat selection in birds is a behavioral, physiological and ecological response (Cody 1985), which may result in a disproportionate use of habitat, directly influencing its survival (Hutto 1985).
However, resource availability for birds in disturbed habitats can be diminished, affecting intraspecific competition (Greenberg 1986), nest predation (Rodewald et al. 2011) and food availability (Kohut et al. 2009).

Research on habitat requirements and behavior of migratory birds has almost exclusively occurred at temperate latitudes (e.g., Dilger 1956, Blake \& Karr 1987, Saab 1999, Norris et al. 2004), such that information on even basic aspects of the natural history of most migratory birds that breed in the Neotropics is still scarce. One such species is the Streaked Flycatcher (Myiodynastes maculatus), which occurs throughout most of the South and Central America and includes seven subspecies. The southernmost population refers to the subspecies $M$. $m$. solitarius, which performs poorly-known migratory movements, breeding in southern South America and moving northwards in the fall (Cueto \& Jahn 2008, del Hoyo et al. 2018). Plumage and vocal differences indicate that this taxon may represent a valid species (del Hoyo et al. 2018), inhabiting different habitat types across South America, including open second-growth, forest edge and small clearings with scattered tall trees, in rural areas or 
even in urban parks (Sick 1997, del Hoyo et al. 2018). However, the basic natural history aspects of this species, such as habitat use and home range size, are still poorly known in both natural and urban areas.

In this study, we assessed the habitat use and estimated the home range size of $M . m$. solitarius during the breeding season in an urban park in Sáo Paulo, Brazil. We aimed to answer three main questions: 1) What is the home range size of the species in urban parks? 2) Does habitat structure influence an individual's home range size? and 3) Does phytophysiognomy influence its foraging behavior?

\section{METHODS}

\section{Study site}

Our study was carried out at the Parque Ecológico do Tietê (hereafter PET), an urban park located between the cities of São Paulo and Guarulhos (Fig. 1). Nearly 300,000 people visit the park each year (DAEE 2019). We focused our research in São Paulo portion. The city is one of the largest and most populous cities in the world (> 12 million people), composed of $>50 \%$ urban structures (e.g., buildings and impervious surfaces), embedded within the Atlantic Forest ecoregion (Muylaert et al. 2018).
We classified the park into three types of areas: A1) Areas formed by partially open vegetation and anthropic structures with relatively high numbers of people and cars, comprised of herbaceous, shrub, arboreous and canopy vegetation strata. The understory is composed by secondary vegetation in an initial state of regeneration, such as Leucaena spp., Enterolobium sp., Cecropia sp., Handroanthus sp., Anadenanthera sp., Bombacopsis sp., Caesalpinia sp., Trema sp., Melia sp., Tipuana sp., Tibouchina sp., and Schinus sp. In the canopy there are native species and exotics, such as Schizolobium sp., Chorisia sp., Jacaranda sp., and mainly Eucalyptus spp. and Casuarina spp. A2). This is a corridor attached to a small fragment of forest with vegetation that is beginning to regenerate, with herbaceous, shrub and arboreous strata present. Here, the understory is composed of reforested native, exotic and ornamental species, such as Tibouchina sp., Handroanthus sp., Libidibia sp., Tipuana sp., Schinus sp., Cedrela sp., Anadenanthera sp., Melia sp., Casuarina sp., Leucaena sp., Ficus spp., Croton sp. and Cecropia sp., as well as Alchornea triplinervia, which is very characteristic of the shrub stratum. A3) Located in an area of the park with limited public access, this area is mainly comprised by forest with tall trees, dominated by Eucalyptus spp. and Casuarina sp.; most of the Eucalyptus is dry or dead (J.G.V., pers. obs.). The understory comprises a less diverse, mostly secondary
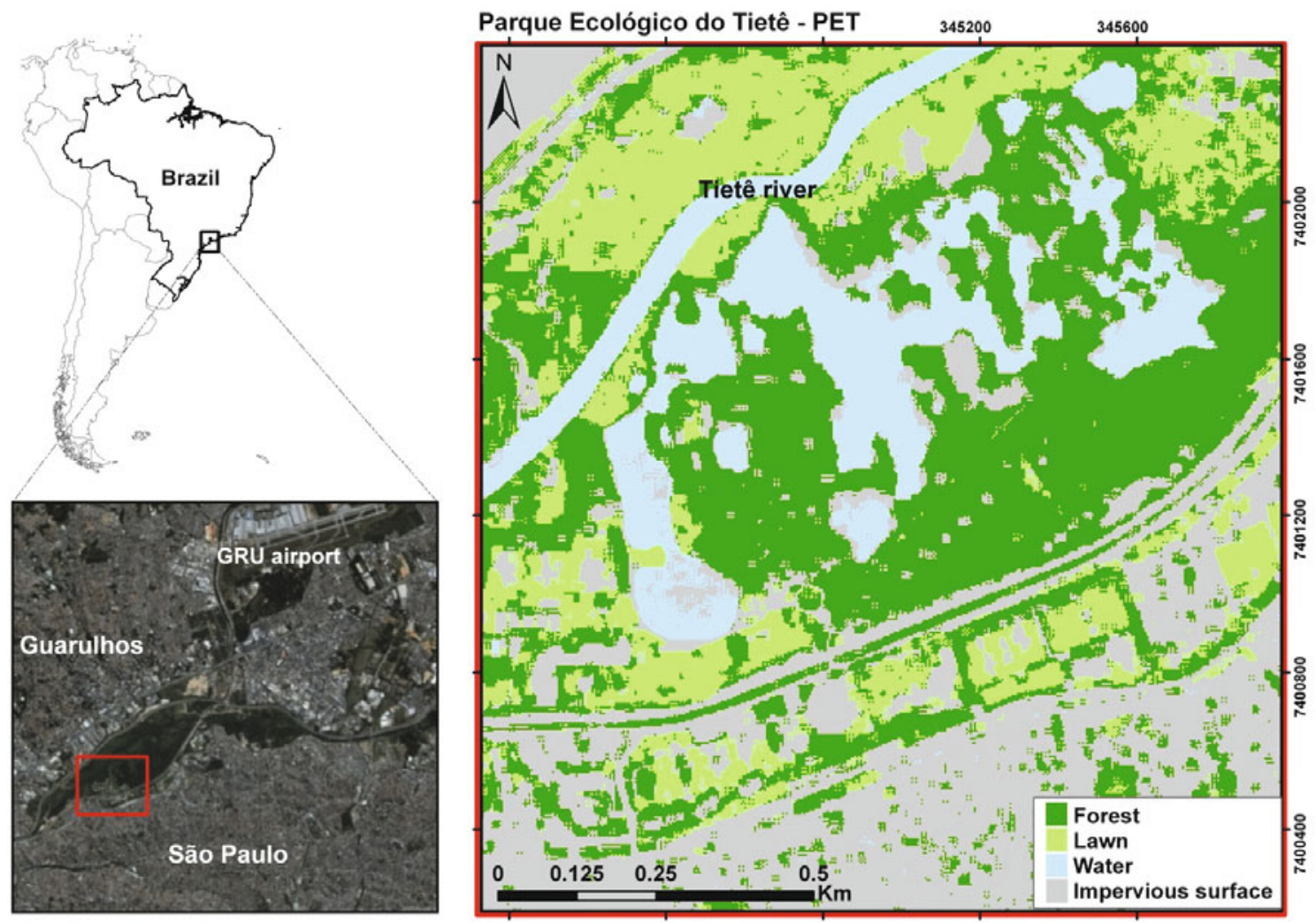

Figure 1. Map of the study area (Parque Ecológico do Tietê - PET) and its landscape components in São Paulo, Brazil. 
plant community, with such species as Anadenanthera spp., Melia sp., Leucaena spp. and Schinus sp. This area is also bordered by a lake.

\section{Fieldwork}

In October 2017, we mist-netted three adult M. m. solitarius, which were banded with numbered and color bands for individual identification. The focal individuals were designated as A1, A2 and A3. They were followed and observed between 17 October 2017 and 31 January 2018 from 06:30 to 10:30 h, using methods described by Altmann (1974). Each individual was followed during 1 $\mathrm{h}$, with its geographic coordinates registered every $10 \mathrm{~min}$ with the cellphone app GPS Geotracker. The following information was collected: date, initial and final time of observation, height of the vegetation stratum it was found in (high 15-20 m, middle 8-15 $\mathrm{m}$ and low 5-8 m), plant species it was found in, type of environment (forest or isolated tree) it was found in, height of the perch (high $15-20 \mathrm{~m}$, middle $8-15 \mathrm{~m}$ and low 5-8 $\mathrm{m}$ ) and stratum of foraging.

Each sampling day started with a different individual in order to minimize any time-related bias in behavioral measurements. The conspicuous vocal behavior of this species made it easy to locate, and individual identification was made using binoculars.

\section{Analyses}

Estimates of home range of $M . m$. solitarius were performed using kernel density estimation (Worton 1987), which is currently the most reliable and accurate home range estimator (Powell 2000, Jacob \& Rudran 2003, Laver \& Kelly 2008). We estimated 95\% kernel density contours to determine the total home range and $50 \%$ kernel density of each individual, and used smoothing (h) and least square cross-validation (LSCV) (Worton 1987, Laver \& Kelly 2008). Analyses were performed using the R 3.4.1 environment ( $\mathrm{R}$ Core Team 2014) and "adehabitat" assembly packages (Calenge et al. 2009). The taxonomy used here follows the Brazilian Committee of Ornithological Records (Piacentini et al. 2015).

\section{RESULTS}

\section{Home range}

The mean home range size of the species was $5.40 \pm 2.45$ ha (95\% kernel density) and $2.46 \pm 1.70$ ha $(50 \%$ kernel density), described for each individual in Table 1. The largest home range, expressed as the $95 \%$ kernel contour was estimated for A1 (8.46 ha) and the smallest was for A3 (2.46 ha; Fig. 2). Home range size varied between months for all individuals, although it was different for each individual (Table 2). The three banded individuals were members of distinct social pairs, and we observed no home range overlap between the territories of each pair. Agonistic encounters were observed between individuals $(n=6)$, but only at home range boundaries.

During the observation of habitat use, we obtained 428 records of the three individuals. Across records, the high tree stratum was the most used $(n=247$ total observations), followed by the middle $(n=141)$ and low strata ( $n=40$; Fig. 3). In general, birds were most often observed using perches in the higher strata (high $=171$, middle $=177)$, followed by the low stratum (low $=80$; Fig. 4). No individuals were seen foraging on the ground. Considering the substrates or perches selected, the $\mathrm{A} 1$ and A3 were similar (high $=11$ and 8, respectively), (middle $=4$ and 8 , respectively) and (low $=5$ and 5 , respectively). While A2 used low perches in most capture activities (low $=33)$, followed by middle perches $(n=17)$. Moreover, in a total of 92 records, $84 \%$ of consumed food items were arthropods and $16 \%$ fruit. Individuals had a clear preference for forest habitats $(n=408)$ in comparison to open areas with isolated trees $(n=20$; Fig. 5$)$. Most

Table 1. Myiodynastes $m$. solitarius home range (ha), expressed as $50 \%$ and $95 \%$ kernel density of three individuals at Parque Ecológico do Tietê, São Paulo city, Brazil. SD = standard deviation.

\begin{tabular}{lll}
\hline ID & $\mathbf{5 0 \%}$ & $\mathbf{9 5 \%}$ \\
\hline A1 & 1.41 & 8.46 \\
A2 & 0.70 & 5.28 \\
A3 & 0.35 & 2.46 \\
\hline
\end{tabular}

Mean \pm SD $\quad 2.46 \pm 1.70$

$5.40 \pm 2.45$

Table 2. Myiodynastes m. solitarius home range (ha) according to $50 \%$ and $95 \%$ kernel density of three individuals of the species at Parque Ecológico do Tietê, Sáo Paulo city, Brazil.

\begin{tabular}{|c|c|c|c|c|c|c|}
\hline \multirow{2}{*}{ Id } & \multicolumn{2}{|c|}{ October } & \multicolumn{2}{|c|}{ November } & \multicolumn{2}{|c|}{ December } \\
\hline & $50 \%$ & $95 \%$ & $50 \%$ & $95 \%$ & $50 \%$ & $95 \%$ \\
\hline A1 & 0.0 & 1.03 & 1.06 & 5.63 & 2.28 & 9.78 \\
\hline A2 & 0.34 & 0.68 & 0.70 & 3.16 & 0.33 & 1.63 \\
\hline A3 & 0.68 & 1.70 & 1.06 & 4.93 & 0.65 & 2.61 \\
\hline
\end{tabular}




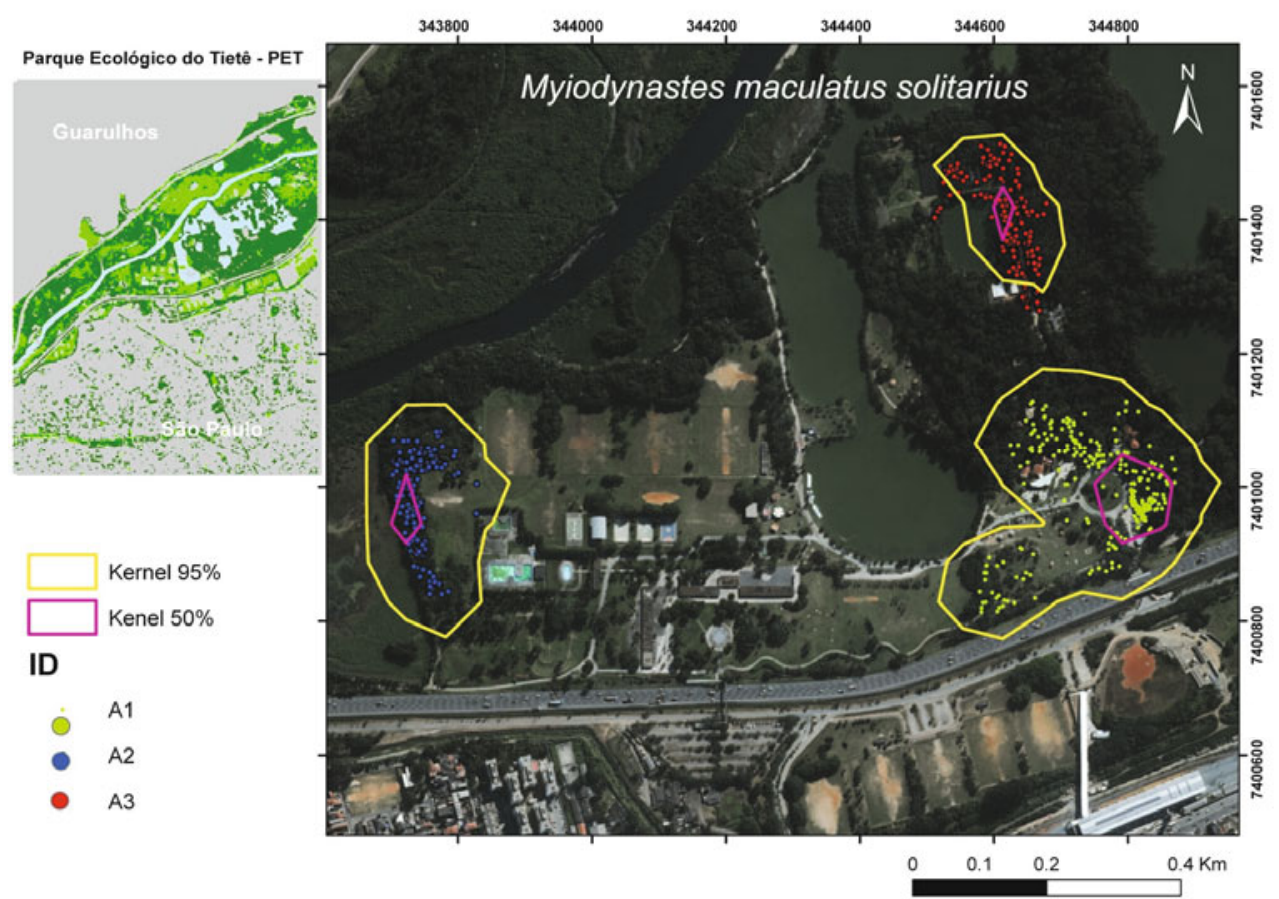

Figure 2. Points within polygons represent georeferenced fixes of observations of each bird during monitoring yellow polygons represent the 95\% kernel density contours and pink polygons represent 50\% kernel density, at Parque Ecológico do Tietê - SP, Brazil.

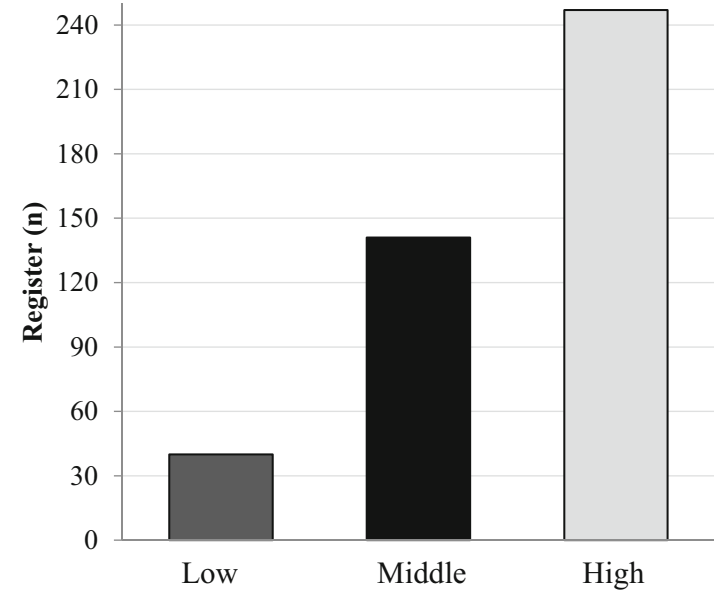

Figure 3. Tree strata used by Myiodynastes maculatus solitarius at Parque Ecológico do Tietê, Brazil.

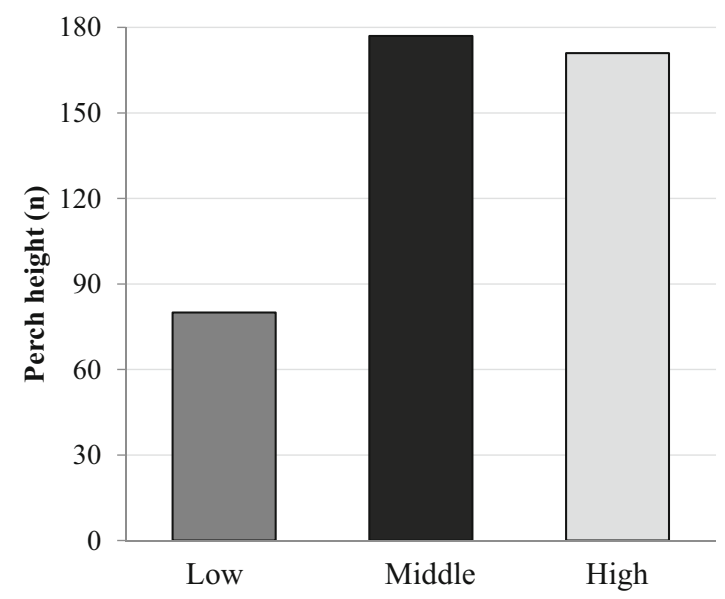

Figure 4. Height of perches used by Myiodynastes maculatus solitarius at Parque Ecológico do Tietê, Brazil.

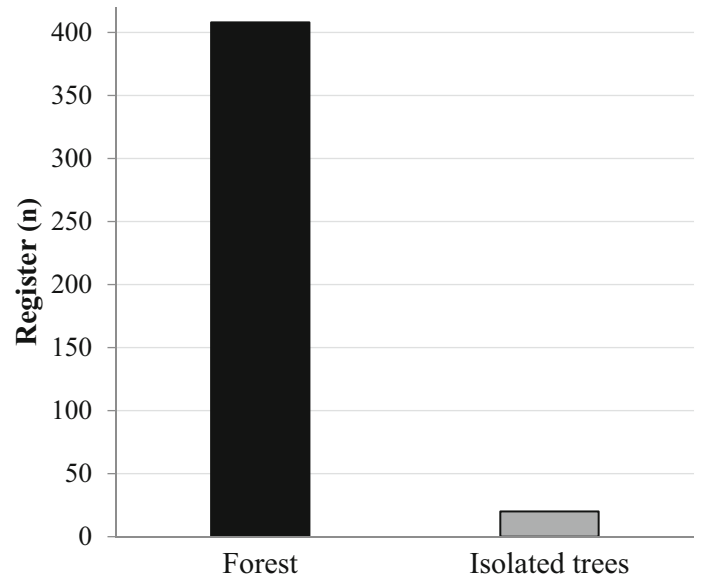

Figure 5. Habitat (forest or isolated trees) used by Myiodynastes maculatus solitarius at Parque Ecológico do Tietê, Brazil.

observations in areas with isolated trees were of the A2 pair. The members of the pairs remained together during the entire observation period and we observed breeding activities of the A2 pair, which nested and produced three fledglings (Figs. 6A \& 6B).

\section{DISCUSSION}

Information on home range size of birds in South American urban areas are scarce and have been estimated for only a few species (e.g., Marantz et al. 2003, Hansbauer et al. 2008, Hilty 2011). As far as we know, this is the first assessment of the home range and habitat use of $M . m$. solitarius and our findings showed that its home range in 

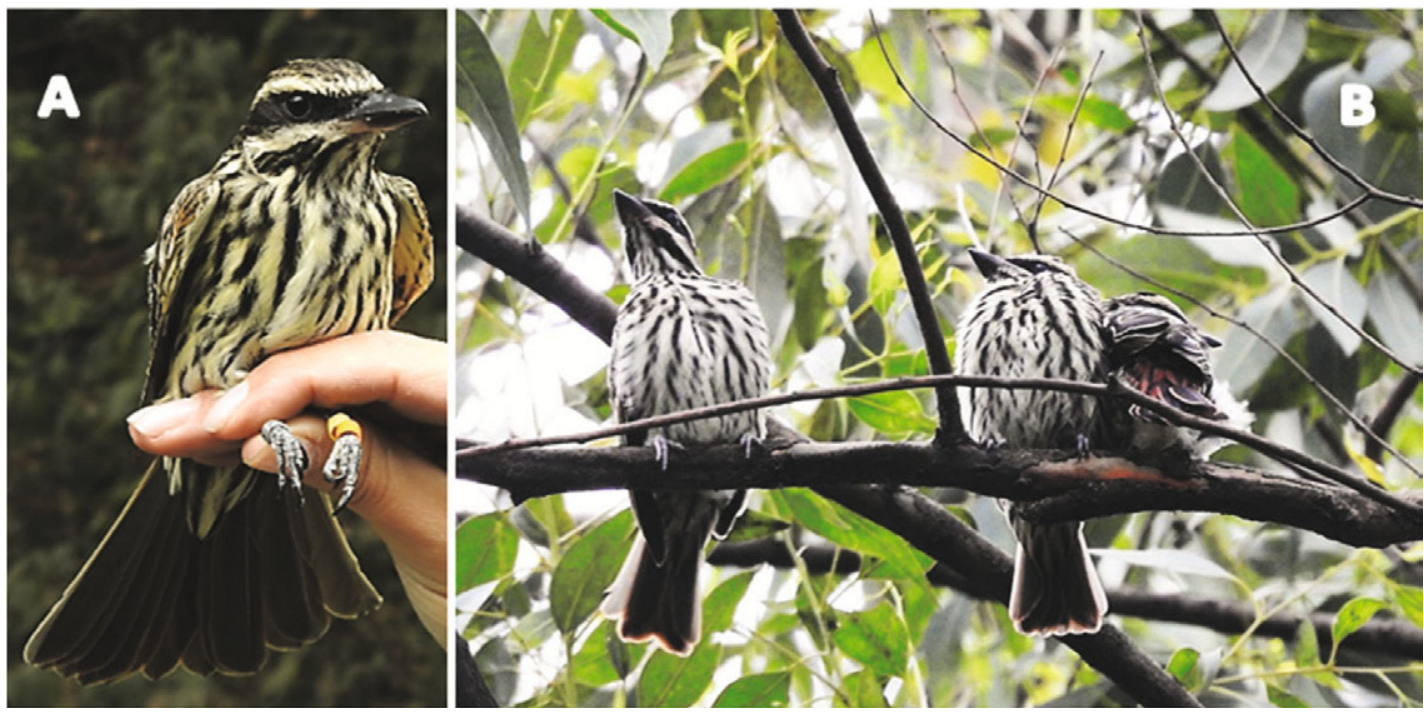

Figure 6. Banded Myiodynastes maculatus solitarius individuals at Parque Ecológico do Tietê, Brazil. (A) Individual A2, and (B) three chicks belonging to A2.

an urban area is smaller than those of most Tyrannidae species studied in natural areas (e.g., Ribeiro et al. 2002, Lopes \& Marini 2006, Jahn et al. 2010). Additionally, the presence of anthropogenic structures, as well as vegetation homogenization may increase the home range, since we registered $M . m$. solitarius feeding on fruits and arthropods, and in urban green areas food availability can be affected (Karr 1976, Jokimaki 1999).

Most of the work on home ranges of tyrant flycatchers in South America have been conducted in natural environments. In the rupestrian fields of Minas Gerais, the estimated home range size of Knipolegus lophotes (a species smaller than M. maculatus), is around 7 ha (Ribeiro et al. 2002) and in the Brazilian Cerrado, two Suiriri Flycatchers (Suiriri suiriri and Suiriri affinis) have home range sizes of up to 14.0 ha and 11.2 ha, respectively, both species using the canopy more often than other strata in Cerrado forest habitat (Lopes \& Marini 2006). Another austral migrant, Tyrannus melancholicus, has a home range of $43.0 \pm 22.6$ ha for males and $45.6 \pm 45.5$ ha for females in the Bolivian Cerrado (Jahn et al. 2010), and in a mature terra-firme forest in the Peruvian Amazon, the austral migratory species Legatus leucophaius has a territory size of -7 ha (Terborgh et al. 1990). Other studies have found that home ranges in urban environments are smaller than in rural or natural areas (e.g., Roth-II et al. 2008, Chiang et al. 2012) and it can explain the size of home range in our results in comparison with other species of the family. Yet, the underlying mechanisms driving these patterns are still poorly understood, since a variety of interacting factors likely influence home range size in birds, including body size (Terborgh et al. 1990), foraging strategies (Jahn et al. 2010) and food availability (Newton 1979, Chiang et al. 2012), quality and structure of habitat (Chiang et al.
2012), sex and age, breeding period and time of the year (Hansbauer et al. 2008, Jahn et al. 2010).

We detected slight differences between the monitored pairs occupying different habitats, which was reflected in the size of their respective home ranges and in the way individuals used the site. The home range of A1 was more anthropized, and throughout the study this individual increased its home range from 2.31 to 6.84 ha, which is potentially due to its foraging strategy to secure sufficient food (Hansbauer et al. 2008). It was also possibly related to the termination of the reproductive period, after which birds are less restricted to being near the nest site (Hutto 1985). Moreover, the reduced tree cover in Al's home range may have contributed to its larger area. Here, the landscape is partially composed of lawn and buildings near the park entrance, where there is more circulation of people and cars (i.e., the total area of buildings and impermeable anthropic structures occupy 0.81 ha of $A 1$ 's home range). On the other hand, the landscape in A3's home range was mostly made up of forest with tall trees, including many Eucalyptus and dead trees, with only $\sim 0.24$ ha being composed of anthropic structures. In contrast, A2's home range was primarily composed of habitat with higher tree species richness, including native species. Moreover, in this area there are no anthropic structures and the landscape is only composed of forest intersected by a narrow trail, which potentially explains the smaller home range. A2 and its mate were also the only pair that nested and successfully reproduced, producing three fledglings (Fig. 6B).

Studies have shown that breeding birds may reduce their home range size during the egg and nestling stages (Amaral \& Macedo 2003, Moraes et al. 2018). Our data refute those results, since in November the area occupied by $\mathrm{A} 2$ was larger, when the pair had nestlings and 
perhaps needed to fly distantly to search for food to feed themselves and their offspring. Although large gaps in information still remain on home range size and habitat requirements of birds in urban parks, most studies to date have found a negative effect of urbanization on breeding birds in urban green spaces, in comparison to those in rural areas (e.g., Bezzel 1985, Jokimaki 1999, Shustack \& Rodewald 2010). For example, in an urban park in Ohio, U.S.A., the migratory flycatcher Empidonax virescens was negatively affected by urbanization, altering its breeding schedule, such that it nested later and had less time to breed (Shustack \& Rodewald 2010). Insectivorous birds that nest in cavities, such as $M$. $m$. solitarius, may also be especially affected by the presence of anthropic structures, as shown in a study on two species of the family Muscicapidae: Ficedula hypoleuca and Muscicapa striata (Jokimaki 1999).

Habitat selection by insectivorous birds is usually related to their ability to find, catch and handle insect prey, activities that can be facilitated in certain types of vegetation structure (Cody 1981). Myiodynastes m. solitarius can be found in several different types of habitat, even in more open urban green spaces (del Hoyo et al. 2018). However, the individuals we observed presented a clear preference for forested habitats in our study, since nearly $95 \%$ of the records were in places with more tree cover and more complex vegetation structure. On the other hand, the species appears to be adapted to breed in a wide diversity of habitat types, including areas where Eucalyptus is present (Marsden et al. 2001, Pereira et al. 2015). Based on personal observations of other individuals in the study area, we noticed the constant use of Eucalyptus for perching, foraging or nesting by $M . m$. solitarius, normally when the tree is dead and has cavities. In the study area, Eucalyptus are usually taller than other tree species, allowing $M . m$. solitarius that use Eucalyptus to perch and move in higher strata of the vegetation. A1 and $\mathrm{A} 3$ showed a clear preference to perch and forage in the middle and higher strata ( $81 \%$ of visualizations), as is typical of the species (e.g., Sick 1997). The complexity of the vegetation contributes to resource availability for birds (MacArthur \& MacArthur 1961), especially for insectivorous birds (Karr 1976), with vegetation structure and food supply usually positively related (Karr 1976). In many cases, a species can adapt to characteristics of the landscape changing their behavior and home range (Chiang et al. 2012). Even though M. m. solitarius presented some plasticity in terms of its habitat use, our results suggest that the tree cover is important for the species.

The PET is certainly an important breeding habitat for this and other migratory bird species, offering resources absent in other green spaces in São Paulo (Barbosa et al. in prep.). Basic information about a species' ecology, such as home range size and habitat use, provides crucial information to develop effective conservation planning (e.g., Luck 2002, Oppel et al. 2004). Our study contributes to improving our understanding on various aspects of the natural history $M . m$. solitarius in an urban area in the Atlantic Rainforest, and highlights the importance of urban green spaces such as the Parque Ecológico do Tietê for the conservation of migratory bird species that breed in the region or stopover during migration.

\section{ACKNOWLEDGEMENTS}

We are in debt to Conselho Nacional de Pesquisa e Desenvolvimento (CNPq) for the fellowship to J.B.V. and the Coordenaçâa de Aperfeiçoamento de Pessoal de Nivel Superior (CAPES) for the scholarship to K.V.C.B. We are also grateful to Idea Wild for the mist nets used in the study; to the Secretaria de Estado de Meio Ambiente (SEMA) for permits to conduct the study at PET; to the Institute Chico Mendes of Biodiversity Conservation for the permits (ICMBio/SISBIO No. 53860-2); to the team of CRAS - PET for the help and assistance in different stages of the study; to Thiago V.V. Costa for help with fieldwork and comments on the manuscript, to Carlos Gussoni and Natália Stefanini for all the support with the analysis of home range areas; and Alex Jahn that kindly reviewed the English.

\section{REFERENCES}

Altmann J. 1974. Observational study of behavior: sampling methods. Behaviour 49: 227-267.

Amaral M.F. \& Macedo R.H.F. 2003. Breeding patterns and habitat use in the endemic Curl-crested Jay of central Brazil. Journal of Field Ornithology 74: 331-340.

Barbosa K.V.C., Rodewald A.D., Ribeiro M.C. \& Jahn A.E. in prep. Noise level and water availability drive species richness of resident and migratory birds within a Neotropical megacity. Unpublished Report.

Bezzel E. 1985. Birdlife in intensively used rural and urban environments. Ornis Fennica 62: 90-95.

Blake J.G. \& Karr J.R. 1987. Breeding birds of isolated woodlots: area and habitat relationships. Ecology 68: 1724-1734.

Brown J.L. \& Orians G.H. 1970. Spacing patterns in mobile animals. Annual Review of Ecology and Systematics 1: 239-262.

Burt W.H. 1943. Territoriality and home range concepts as applied to mammals. Journal of Mammalogy 24: 346-352.

Calenge C., Dray S. \& Royer-Carenzi M. 2009. The concept of animals' trajectories from a data analysis perspective. Ecological Informatics 4: 34-41.

Chiang S.N., Bloom P.H., Bartuszevige A.M. \& Thomas S.E. 2012. Home range and habitat use of Cooper's Hawks in urban and natural areas. Studies in Avian Biology 45: 1-16.

Cody M.L. 1981. Habitat selection in birds: the roles of vegetation structure, competitors and productivity. BioScience 31: 107-113.

Cody M.L. 1985. Habitat selection in birds. New York: Academic Press.

Cueto V.R. \& Jahn A.E. 2008. Sobre la necessidad de tener un nombre 
estandarizado para las aves que migran dentro de América del Sur. Hornero 23: 1-4.

DAEE [Departamento de Águas e Energia Elétrica]. 2019. Parque Ecológico do Tietê. http://www.daee.sp.gov.br/index. php?option $=$ com_content $\& v i e w=$ article $\&$ id $=564$ : parque ecologico-do-tiete-pq\&catid=48:noticias\&Itemid=53 (Access on 06 August 2019).

del Hoyo J., Collar N. \& Kirwan G.M. 2018. Southern Streaked Flycatcher (Myiodynastes solitarius). https://www.hbw.com/ node/1343708 (Access on 05 September 2018).

Dilger W.C. 1956. Adaptive modification and ecological isolating mechanisms in the thrush genera Catharus and Hylocichla. Wilson Bulletin 68: 171-199.

Greenberg R. 1986. Competition in migrant birds in the nonbreeding season. Current Ornithology 3: 281-307.

Hansbauer M.M., Storch I., Leu S., Nieto-Holguin J.P., Pimentel R.G., Knauer F. \& Metzger J.P. 2008. Movements of Neotropical understory passerines affected by anthropogenic forest edges in the Brazilian Atlantic Rainforest. Biological Conservation 141: 782-791.

Hilty S.L. 2011. Family Thraupidae (tanagers), p. 46-329. In: del Hoyo J., Elliot A. \& Christie D. (eds.). Handbook of the birds of the world, v. 16 (tanagers to New World blackbirds). Barcelona: Lynx Editions.

Hutto R.L. 1985. Habitat selection by nonbreeding, migratory land birds, p. 455-476. In: Cody M.L. (ed.). Habitat selection in birds. New York: Academic Press.

Jacob A.A. \& Rudran R. 2003. Radiotelemetria em estudos populacionais, p. 285-342. In: Valladares-Padua C., Bodmer R.E. \& Cullen-Jr. L. (eds.). Manejo e conservação da vida silvestre no Brasil. Belém: Sociedade Civil Mamirauá.

Jahn A.E., Ledezma J.P., Mamani N.A., DeGroote L.W. \& Levey D.J. 2010. Seasonal home range size of Tropical Kingbird (Tyrannus melancholicus) in the southern Amazon Basin. Ornitologia Neotropical 21: 39-46.

Jokimaki J. 1999. Occurrence of breeding bird species in urban parks: effects of park structure and broad-scale variables. Urban Ecosystems 3: 21-34.

Karr J.R. 1976. Seasonality, resource availability, and community diversity in tropical bird communities. American Naturalist 110: 973-994.

Kohut S.M., Hess G.R. \& Moorman C.E. 2009. Avian use of suburban greenways as stopover habitat. Urban Ecosystems 12: 487-502.

Laver P.N. \& Kelly M.J. 2008. A critical review of home range studies. Journal of Wildlife Management 72: 290-298.

Lees A.C. \& Martin R.W. 2015. Exposing hidden endemism in a Neotropical forest raptor using citizen science. Ibis 157: 103-114.

Leveau L.M. 2018. Urbanization, environmental stabilization and temporal persistence of bird species: a view from Latin America. PeerJ 6: e6056.

Lopes L.E. \& Marini M.A. 2006. Home range and habitat use by Suiriri affinis and Suiriri islerorum (Aves: Tyrannidae) in the central Brazilian Cerrado. Studies on Neotropical Fauna and Environment 41: 87-92.

Luck G.W. 2002. The habitat requirements of the Rufous Treecreeper (Climacteris rufa): preferential habitat use demonstrated at multiple spatial scales. Biological Conservation 105: 383-394.

MacArthur R.H. \& MacArthur J.W. 1961. On bird species diversity. Ecology 42: 594-598.

Marantz C.A., Aleixo A., Bevier L.R. \& Patten M.A. 2003. Dendrocolaptidae (woodcreepers), p. 358-447. In: del Hoyo J., Elliot A. \& Christie D. (eds). Handbook of the birds of the world, v. 8 (broadbills to tapaculos). Barcelona: Lynx Editions.
Marsden S.J.,Whiffin M. \& Galetti M. 2001. Bird diversity and abundance in forest fragments and Eucalyptus plantations around an Atlantic Forest reserve, Brazil. Biodiversity and Conservation 10: 737-751.

Martin T.E. \& Finch D.M. 1995. Ecology and management of Neotropical migratory birds: a synthesis and review of critical issues. New York: Oxford University Press.

Moraes A.L.B., Silveira N.S. \& Pizo M.A. 2018. Nocturnal roosting behavior of the Pale-breasted Thrush (Turdus leucomelas) and its relation with daytime area of use. Wilson Journal of Ornithology 130: 828-834.

Muylaert R.L., Vancine M.H., Bernardo R., Oshima J.E.F., SobralSouza T., Tonetti V.R., Niebuhr B.B. \& Ribeiro M.C. 2018. Uma nota sobre os limites territoriais da Mata Atlântica. Oecologia Australis 22: 302-311.

Newton I. 1979. Population ecology of raptors. London: Buteo Books.

Norris D.R., Marra P.P., Kyser T.K., Sherry T.W. \& Ratcliffe L.M. 2004. Tropical winter habitat limits reproductive success on the temperate breeding grounds in a migratory bird. Proceedings of the Royal Society of London B: Biological Sciences 271: 59-64.

Oppel S., Schaefer H.M., Schmidt V. \& Schroder B. 2004. Habitat selection by the Pale-headed Brush-finch (Atlapetes pallidiceps) in southern Ecuador: implications for conservation. Biological Conservation 118: 33-40.

Pereira H.S., Pires M.R.S., Azevedo C.S. \& Ribon R. 2015. Riqueza e densidade de aves que nidificam em cavidades em plantaçóes abandonadas de eucalipto. Papéis Avulsos de Zoologia 55: 81-90.

Piacentini V.Q., Aleixo A., Agne C.E., Maurício G.N., Pacheco J.F., Bravo G.A., Brito G.R.R., Naka L.N., Olmos F., Posso S., Silveira L.F., Betini G.S., Carrano E., Franz I., Lees A.C., Lima L.M., Pioli D., Schunck F., Amaral F.R., Bencke G.A., Cohn-Haft M., Figueiredo L.F.A., Straube F.C. \& Cesari E. 2015. Annotated checklist of the birds of Brazil by the Brazilian Ornithological Records Committee. Revista Brasileira de Ornitologia 23: 91-298.

Powell R.O. 2000. Animal home ranges and territories and home range estimators. In: Pearl M.C. (ed.). Research techniques in animal ecology: controversies and consequences. New York: Columbia University Press.

R Core Team. 2014. R: a language and environment for statistical computing. Vienna: R Foundation for Statistical Computing.

Ribeiro B.A., Goulart M.F. \& Marini M.A. 2002. Aspectos da territorialidade de Knipolegus lophotes (Tyrannidae, Fluvicolinae) em seu período reprodutivo. Ararajuba 10: 231-235.

Rodewald A.D., Kearns L.J. \& Shustack D.P. 2011. Anthropogenic resources decouple predator-prey relationships. Ecological Applications 21: 936-943.

Roth-II T.C., Vetter W.E. \& Lima S.L. 2008. Spatial ecology of winting Accipiter Hawks: home range, habitat use, and the influence of bird feeders. Condor 110: 260-268.

Saab V. 1999. Importance of spatial scale to habitat use by breeding birds in riparian forests: a hierarchical analysis. Ecological Applications 9: 135-151.

Shustack D.P. \& Rodewald A.D. 2010. Attenuated nesting season of the Acadian Flycatcher (Empidonax virescens) in urban forests. Auk 127: 421-429.

Sick H. 1997. Ornitologia brasileira. Rio de Janeiro: Nova Fronteira.

Terborgh J., Robinson S.K., Parker-III T.A., Munn C.A. \& Pierpont N. 1990. Structure and organization of an Amazonian Forest bird community. Ecological Monographs 60: 213-238.

Worton B.J. 1987. A review of models of home range for animal movement. Ecological Modelling 38: 277-298.

Associate Editor: Carla S. Fontana. 